\title{
Locative Relatives in Durban Zulu
}

\author{
Lisa L.-S. Cheng \\ Leiden University \\ Laura J. Downing \\ ZAS
}

This paper examines locative relatives in Durban Zulu. We show that locative relatives differ from nominal relatives crucially in prosodic phrasing as well as in resumptive pronoun marking. We propose that the best way to account for locative relatives in Zulu is to resort to the old style adjunction analysis of relative clauses, with an empty operator. The system we propose assumes that such an adjunction analysis co-exists with a head-raising analysis, which accounts for the nominal relative clauses.

\section{Introduction}

Whether locative phrases in Bantu languages are nominals or adverbials has been a rather controversial issue. Using locative inversion sentences, Bresnan and Kanerva (1989) and Bresnan (1994) argue that locatives in Chichewa are noun phrases. Bresnan (1994) in particular argues that inverted locatives function as grammatical subjects, using evidence from agreement, control and raising, as well as the differences from their counterparts in English. Demuth (1990), on the other hand, shows that inverted locatives in Sesotho do not function as subjects. She then argues that locatives in Sesotho are adverbs.

In this paper, we discuss data from relative clauses, and show that locatives in Zulu are adverbials. We first show that relatives which involve a nominal head noun differ from relatives involving a locative or adverbial head in prosody, and in resumptive pronoun marking. We then discuss different strategies of relative clause formation. We argue that these distinctions in prosody and the resumptive pronoun marking can be accounted for in $\mathrm{Zulu}$, if nominal relatives are derived by a head raising strategy (à la Kayne 1994), while locative or adverbial relatives are derived by an adjunction analysis. 


\section{Background}

In order to understand the special properties of locative relatives in Zulu, we first must take a look at the morphology of locatives and at the prosody and structure of non-locative relatives.

\subsection{Locative morphology in Zulu}

Zulu differs from some Bantu languages in that it does not have an active morphological contrast between locative classes 16,17 , and 18 . Only class 17 is active in the agreement system (see Buell 2007 for more detailed discussion). In Zulu, locatives can be derived from nouns by several morphological strategies. Buell (2007) makes a distinction between "formal" and "semantic" locatives. Formal locatives are the ones that contain locative morphology. For example, in (1), we see examples of locatives derived by prefixing $e$ and (optionally) suffixing (w)ini/eni to the noun. Locatives can also be derived by procliticizing locative particles: $k u$-pronoun $/ \mathrm{N}$, pha-N, or $k w a-\mathrm{N} /$ pronoun. In (2a-b) are examples adapted from Buell (2007) illustrating this strategy. There are also a few locative prepositionals in Zulu.

"Semantic" locatives are nominals which are clearly locative in meaning, but which lack locative morphology. An example of this type of locative is lezi zindlu 'these houses' in (2c): ${ }^{1}$
a. Ú-hlál'
é-dolóbh-e:ni.
1sM-live
LOC-5.city-LOC
'S/he lives in the city centre.'
b. Ú-nge:n'
é-ndl-i:ni.
1sM-enter
LOC-9.house-LOC
'S/he entered the house.'
a. Aba-ntu
aba-dala
ba-hlala ku-lezi
zi-ndlu.
2-peopl
2SM-stay LOC-10.these
10-houses
'Old people live in these houses.'

\footnotetext{
1 In the data, high tones are marked with an acute accent and low tones are unmarked, except the copular low tone morpheme is marked with a grave accent. Buell (2007) does not mark tone or phrasal lengthening; for this reason, this information is missing from data cited from this source.

The following abbreviations are used in the morpheme glosses: numbers indicate noun agreement class; $\mathrm{SM}=$ subject marker; $\mathrm{OM}=$ object marker; $\mathrm{TAM}=$ tense-aspect marker; NEG $=$ negative $; \mathrm{INF}=$ infinitive $\mathrm{COP}=$ copula $; \mathrm{REL}=$ relative; $\mathrm{LOC}=$ locative; $\mathrm{PT}=$ participial; $\mathrm{FUT}=$ future; $\mathrm{DJ}=$ disjoint; $\mathrm{DEM}=$ demonstrative; $\mathrm{PREP}=$ preposition .
} 
b. Ku-lezi zi-ndlu ku-hlala (khona) aba-ntu aba-dala. LOC-10.these 10-houses 17SM-stay there 2-people 2-old 'In these houses live old people.'

c. Lezi zi-ndlu zi-hlala aba-ntu aba-dala. 10.these 10-houses 10SM-live 2-people 2-old 'Old people live in these houses.'

Postverbal locatives, like other adjuncts, canonically follow all argument complements of the verb, as shown in (3):
a. Ú-Síph' ú-phek' ín-ku:kh' é-mz-ini wam' ízo:lo. 1-Sipho 1SM-cook 9-chicken LOC-3.house-LOC 3.my yesterday 'Sipho cooked chicken at my house yesterday.'
b. Ó:-thisha bá-theng-é ízin-cwâ:d' é-dolóbh-en' ízo:lo. 2-teacher 2SM-buy-TAM 10-book LOC-5.city-LOC yesterday 'The teachers bought books in town yesterday.'

Cheng and Downing (to appear, b) show that these ordering facts can be accounted for if (non-focused) locative adjuncts are right-adjoined to an XP above the $v \mathrm{P} .^{2}$

\subsection{The basics of relative clauses in Zulu}

\subsubsection{Relative morphology \& prosodic phrasing}

Zulu non-adverbial relative clauses contain a participial verb, with relative subject morphology. (See e.g., Doke 1961 for more detailed discussion of this morphology.) Relatives do not employ relative pronouns or special relative markers. Instead, the relative verb is marked for agreement with what appears to be its head. ${ }^{3}$ In subject relatives, the agreement is realized in the relative verb's subject prefix, which accords with the noun class of the head of the relative, as illustrated in $(4 a, b)$ :
a. Ín-dod'
[é-gqoke
ísí-gqo:ko] í-bon-é
ízi-vaká:shi.
9-man
REL9-wear 7-hat
9SM-see-TAM
8-visitor
'The man who is wearing a hat saw the visitors.'

2 Focused locatives, like other focused non-subjects, must occur in Immediately After the Verb position, in the case of locatives, left-adjoined to $v$ P. See Cheng \& Downing (to appear, b) for detailed discussion.

3 See Zeller (2004) for detailed discussion of the relative morphology of the Nguni languages. 

b. Si-hlek'
ábá-ntwán’
[ábá-jah'
ím-bû:zi].
we.sM-laugh.at 2-child
REL2-chase
9-goat
'We laugh at the children who are chasing the goat.'

For non-subject relatives, there is no relative agreement with the head of the relative clause. However, either an agreeing object marker (italicized) is prefixed to the relative verb, or some other form of resumptive morphology occurs in the relative clause:
a. (Si-thánd' ísí-gqok' [ín-dod' é-si-gqok-ilê:-yo]). we.SM-like 6-hat 9-man REL9-6OM-wear-TAM-REL
'We like the hat the man is wearing.'
b. (Ín-dod' [ízi-nj' ézí-yí-jahâ:-yo]) (í-ntshóntsh' í-qhû:de). 9-man 10-dog REL10-9OM-chase-REL 9SM-steal 5-rooster 'The man who the dogs are chasing stole a rooster.'

The data in (5) also show the prosodic phrasing pattern for restrictive relatives discussed in Cheng and Downing (2007, 2009): the restrictive relative clause and the relative head are parsed into the same prosodic phrase, and the first phrase break falls at the right edge of the relative clause. ${ }^{4}$ The prosodic phrase boundaries can be easily identified in the data by the position of lengthened penult vowels. Vowel length is not contrastive, and long vowels are mainly found in the penult syllables of some words. Work since Doke (1961) analyzes penult length as a correlate of stress, and since Khumalo (1987) it is accepted that penult lengthening is a phrase level (not lexical) process.

The phrasing for restrictive relatives is further illustrated in (6), where we see that the head of the relative clause, regardless of whether it is a subject relative or an object relative, is phrased together with the relative clause (underlined); there is no prosodic phrase break between the head and the relative clause.
a. (Úm-fúndísi [ó-thól-ê: ín-dánda:tho]) (ú-zo-thóla úm-klóme:lo). 1-teacher REL1-find-TAM 9-ring 1SM-FUT-get 3-reward 'The teacher who found the ring will get a reward.'
b. (Ú-gó:go) (ú-phék' úku-dl' [ábá-ntwan'ábá-ku-thánda:-yo]). 1-grandmother 1SM-cook 15-food 2-child REL2-15OM-like-REL 'Grandmother cooks food which the children like.'

Non-restrictive relative clauses, like restrictive relatives, contain a participial verb with relative morphology. Within the non-restrictive subject relative clause,

4 Prosodic phrases are indicated by parentheses. Square brackets indicate syntactic constituent edges and are used mainly to highlight the relative clauses. 
there is also a relative subject marker of the same noun class as the head, and in the case of object relatives, an agreeing object marker (italicized) is prefixed to the relative verb. However, they manifest a different prosodic phrasing. As shown in $(7 a, b)$, the head of the non-restrictive relative clause is phrased separately from the relative clause:
a. (Ú-nhla:nhlá) ([ó-thénge ámá-tha:ngá]) (ú-wá-thwéle ng-ó-bhasikí:di). 1-Nhlanhla REL1-buy 6-pumpkin 1SM-6OM-carry with-1a-basket 'Nhlanhla, who bought the pumpkins, is carrying them in a basket.'
b. (Si-mem' ú-Ja:bu) ([o-m-ázi:-yo]) é-dil-î:ni). we.SM-invite 1-Jabu RELyou-1OM-know-REL LOC-9.party-LOC 'We are inviting Jabu, who you know, to the party.'

Clefts show the same prosodic phrasing as non-restrictive relative clauses. Clefts in Zulu have a bipartite structure, consisting of a copular clause and a relative clause (when the pivot in the copular clause is a non-adverbial). ${ }^{5}$ As we can see in $(8 \mathrm{a}, \mathrm{b})$, the relative clause half of the cleft is prosodically phrased separately from the copular clause:
a. (Ùm-fúndí:si) ([ó-thól-ê:
ín-dándatho e-bí-ngi-láhléké:le]). COP.1-teacher REL1-find-TAM 9-ring REL9-TAM-me.OM-lost '(It) is the teacher who found the ring that got lost from me.'
b. (İn-kû:kh') ([ú-Síph' á-yí-phékél’ ú-Thá:ndi kwa-m’ ízo:lo]). COP.9-chicken 1-Sipho REL1-9OM-cook 1-Thandi LOC-my yesterday 'It is chicken that Sipho cooked for Thandi at my house yesterday.'

To sum up the phrasing, a restrictive relative clause systematically phrases together with its head. Non-restrictive relative clauses and the relative clause half of a cleft, in contrast, phrase separately.

\subsubsection{Basic syntactic analyses of relative clauses and clefts in Zulu}

Cheng \& Downing (2007; to appear, a) develop syntactic analyses of restrictive relatives, non-restrictive relatives and clefts which account for these prosodic phrasing generalizations. We summarize the analyses in this section.

Assuming a Kaynian analysis of restrictive relative clauses (see Bianchi 2000 among others for variations of Kaynian analyses), the head of a restrictive

5 See Cheng and Downing (to appear, a) for more details concerning the structure of clefts in Zulu. 
relative is within the $\mathrm{CP}$, and the $\mathrm{CP}$ is a complement of the $\mathrm{D}$ head, as shown in the structure below:

$$
\begin{aligned}
& \text { [DP (Ín-dod' [ízi-nj’ ézí-yí-jahâ:-yo]) (í-ntshóntsh’ í-qhû:de). } \\
& \text { 9-man 10-dog } \\
& \text { 'The man who the dogs are chasing stole a rooster.' }
\end{aligned}
$$

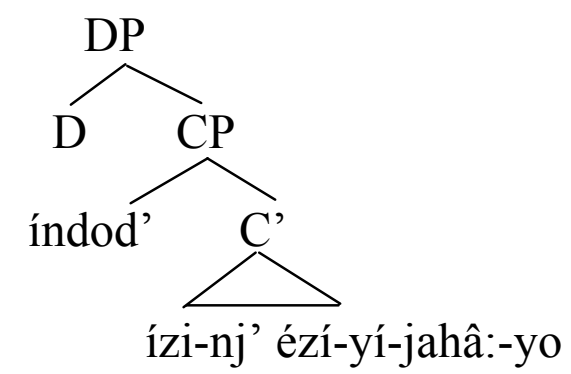

Given this structure, the prosodic phrase break following restrictive relative clauses satisfies the constraints in (10) and (11), motivated in detail in Cheng \& Downing (2007; 2009; to appear, b), requiring the right edges of Intonation Phrases and $v \mathrm{P} / \mathrm{CP}$ phases to coincide in Zulu:

(10) AlignR[Phase, IntPh]: Align the right edge of every phase $(v \mathrm{P} / \mathrm{CP})$ with the right edge of an Intonation Phrase (IntPh).

(11) AlignR[IntPh, Phase]: Align the right edge of every Intonation Phrase $(\mathrm{IntPh})$ with the right edge of a phase $(\mathrm{vP} / \mathrm{CP})$.

It also falls out from these constraints that the relative clause portion of a cleft is parsed into a separate Intonation Phrase. As noted above, clefts in Zulu involve a bipartite structure, illustrated with a sentence with a subject cleft in (6a), repeated here as (12a). We suggest that it has the structure in $(12 b){ }^{6}$
a. (Ùm-fúndí:si) [(ó-thól-ê:
ín-dándatho e-bí-ngi-láhléké:le)]. COP.1-teacher REL1-find-TAM 9-ring REL9-TAM-me.OM-lost '(It) is the teacher who found the ring that got lost from me.'
b. [CP[IPÙm-fúndí:si]][ ${ }_{\mathrm{DP}} \varnothing$ [CP ó-thól-ê: ín-dándatho e-bí-ngi-láhléké:le]].

In this structure, the pivot of the cleft is in a copular sentence, and the headless DP with the relative clause is adjoined to the copular sentence. Similar structures have been proposed for cleft sentences in French by Clech-Darbon et al. (1999) and for cleft sentences in Thompson River Salish by Koch (2008). Given this structure, the pivot of the cleft will be at the right edge of a CP. As

6 See Cheng \& Downing (to appear, a) for detailed motivation for this structure. 
the right edge of $\mathrm{CP}$ consistently conditions a prosodic phrase break in Zulu, this structure correctly accounts for the prosodic parse of clefts.

The constraints so far, though, do not account for the prosodic phrasing of non-restrictive relative clauses. We follow Demirdache (1991) in assuming that a non-restrictive relative is adjoined to the whole DP. The head noun, thus, is not raised from a CP internal position.

(Si-mem’ ú-Ja:bu) ([o-m-ázi:-yo]) é-dil-î:ni).

we.SM-invite 1-Jabu RELyou-1OM-know-REL LOC-9.party-LOC

'We are inviting Jabu, who you know, to the party.'

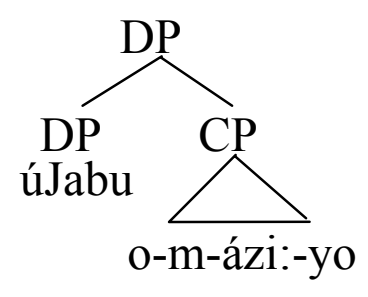

While the fact that the head noun is positioned outside of CP in non-restrictive relatives in this structure does provide a clear-cut syntactic difference between restrictive relatives and non-restrictive relatives, this distinction alone does not directly translate to the prosodic boundary at the left edge of CP that we find in the case of non-restrictive relatives.

To account for the prosodic break between the non-restrictive relative and its head, Cheng \& Downing $(2007,2009)$ propose that the left edge of the CP phase only plays a role when the $\mathrm{CP}$ is not selected, e.g., in a non-restrictive relative clause, with sentential subjects, and in other adjunct clauses. As we can see in the structure in (13), the left edge of $\mathrm{CP}$ in a non-restrictive relative is not selected (by a $\mathrm{D}^{0}$ ), and so it is aligned with a left Intonation Phrase boundary. This proposal is formalized by the following alignment constraint:

AlignL(Phase, I):

Align the left edge of each non-selected phase $(\mathrm{vP} / \mathrm{CP})$ with the left edge of an Intonation Phrase (I).

To sum up this section, Zulu prosodic phrases generally show an asymmetric alignment with syntactic phases: the right edge of an Intonation Phrase coincides with the right edge of a phase. This accounts for the phrasing of relative clauses and clefts, given the syntactic analyses sketched here. However, the left edge of a phase coincides with an Intonation Phrase if the phase is not selected. This accounts for the phrasing break preceding a non-restrictive relative. 


\section{Locative relatives}

With this background in mind, let us now turn to relative clauses related to locatives. This includes cases in which the head of the relative is a locative, or cases in which the head noun is associated with a locative expression. Consider first the sentences in (15). In (15a), the head of the relative clause is an expression with locative marking, endlini 'into the house', while in the relative clause we have typical object marking (agreeing with the head). In (15b), the head of the relative is a noun phrase (without locative marking), but it is associated with a locative resumptive element kuyona 'in there, c1.9', which agrees with the head in noun class. In (15c) is an example with a locative expression as the head, which is associated with a locative resumptive element in the relative clause:
a. (Ú-Síphó ú-ngené é-ndl:-iní)
(ú-Thémba á-yí-thengí:le). 1-Sipho 1SM-enter LOC-9.house-LOC 1-Themba REL1-9OM-bought 'Sipho went into the house that Themba bought.'
b. (Ngi-thánd'í:n-dl') (ú-Síphóá-hlálá kú-yo:na).
I.SM-like 9.house 1-Sipho REL1-live LOC-9.pronoun 'I like the house that Sipho is living in.'
c. (Ú-yê: kú-lé-máke:thé) (ésí-zo-hlangana 1SM-go.TAM LOC-DEM-9.market REL.we-FUT-meet no-Síphó kú-yo:na). with-Sipho LOC-9.pronoun 'She went to the market where we will meet with Sipho.'

In all these cases, regardless of whether the head is marked as a locative or not, the head of the relative clause is prosodically phrased separately from the rest of the relative clause. This pattern of prosodic phrasing differs from that of typical restrictive relatives involving non-locative expressions discussed in the preceding section.

The problem posed by locative relatives is not just limited to the area of prosodic phrasing. Given a head-raising analysis (which we assume for restrictive relative clauses in $\mathrm{Zulu}$ ), a couple of non-trivial issues arise. First, if either the matrix verb or the verb in the relative clause requires an expression marked as locative, a simple head-raising analysis may generate the wrong form or a mismatch in form. In (15a), a non-locative is required in the relative clause, while in the matrix, a locative form is required. Similarly, in (15b), though a locative form is required within the relative clause, the matrix verb dictates a non-locative. Lastly, as we have indicated above, there are different locative markings. If the marking required by the matrix differs from the marking 
required by the relative clause, a mismatch scenario again arises. These "mismatches" are summarized in (16). ${ }^{7}$
a. $\left[\mathrm{CP}^{\text {matrix }} \ldots \mathrm{V} \mathrm{LOC}\right.$ i $\left.\left[\mathrm{CP}^{\mathrm{REL}} \ldots \mathrm{V}\left[\mathrm{DP}^{\mathrm{OM}} \mathrm{i}\right] \ldots\right]\right]$
b. $\left[\mathrm{CP}^{\text {matrix }} \ldots \mathrm{V} \mathrm{DP} \mathrm{P}_{\mathrm{i}}\left[\mathrm{CP}^{\mathrm{REL}} \ldots \mathrm{V}\right.\right.$ LOC-PRON $\left.\left._{\mathrm{i}} \ldots\right]\right]$
c. $\left[\mathrm{CP}^{\text {matrix }} \ldots \mathrm{V} \mathrm{LOC}_{\mathrm{i}}\left[\mathrm{CP}^{\mathrm{REL}} \ldots \mathrm{V}\right.\right.$ LOC-PRON $\mathrm{i}$...] $]$

It should be noted that there is another strategy for modifying locative expressions, namely by using an adverbial clause headed by lapho, with khona in the clause, as in (17):
a. (Ú-Síphó ú-khwélé phé:zu) (kw-é:ndlu) (lapho ú-Thémba 1-Sipho 1SM-climb.past é-hlála kho:na). PT1-live there 'Sipho climbed onto the house where Themba lives.'
b. (Úm-fú:la) (laph' ú-Síphó é-phónzé kho:n')(í-bhólá 3-river lapho 1-Sipho PT1-threw there 5-ball 1-a:khé) (ú-yá-shóna phâ:nsi). 5-his 3SM-DJ-sink down 'The river where Sipho threw his ball is very deep.'
c. (Ú-yê: é-ndaw-é:ni) (laph' ú-Síph' á:-khandelá 1SM-go.TAM LOC-9.place-LOC lapho 1-Sipho PT1.past-fix í-motó y-a:khe) (kho:na).
9-car 9-his there
'He went to the place where Sipho had fixed his car.'

As indicated in $(17 \mathrm{a}-\mathrm{c})$, the lapho...khona clause is prosodically phrased separately from what precedes it, just like the locative relatives in (15), where the relative clause is prosodically phrased separately from the head of the relative clause.

That lapho...khona clauses can also be used without locative expressions is shown in (18) and (19):

7 One may consider using a distributive morphology or a feature-based analysis to avoid the problems stated. For instance, a simple noun phrase raised from the relative clause can have a locative feature added, leading to the spell-out of a locative expression. However, such an account also runs into problems. In particular, for a locative expression raised from the relative clause to a matrix environment which requires a non-locative, it is unclear how the locative feature can be deleted from the locative expression in the matrix. 
(18) (Ú-su:kú) (lapho ú-Sípho é-phékélé é-mz-ini w-á:kho)

11-day lapho 1-Sipho PT1-cook LOC-3.home-LOC 3-your (kho:na) (lú-qalé ka:mbi).

Adv 11sM-begin badly

'The day when Sipho cooked at your house began badly.'

(19) Examples from Doke (1961) - lapho clauses are adverbial clauses
a. Lapho usu-qed-ile, ma-wu-buye. when PT.you-finish-TAM HORT-you.SM-return.SUBJUNCTIVE 'When you have finished, come back.'
b. Yi-beke in-cwadi lapho kade i-khona. 9OM-put.SUBJUNCTIVE 9-book where before COP-there 'Put the book where it was before.'

Note that Zulu is not alone in distinguishing locative relatives from non-locative ones. In English, relative pronouns and the complementizer that cannot be deleted in locative relatives, if the gap is not preceded by a preposition. (See Rothstein 2006, and Larson 1985.)

(20) a. [DP The book] which/that/ø Mary read [DP e ] is out of print.

b. [DP The shop] where/in which/*that/*ø Mary bought the book [pP e ] is on the corner of the street.
c. [DP The shop] Mary bought the book in [PP e ] is on the corner of the street.

\subsection{Issues in interpretation}

The presence of a locative expression in relative clauses does not just present mismatches in form, but also mismatches in interpretation. Consider first a nominal relative clause in (21), with no mismatches.

(21) (Ngi-thánd' í-ndl' [ u-Síph' á-yí-theng-í:le ]).

I.SM-like 9-house 1-Sipho REL1-9OM-buy-TAM 'I like the house that Sipho bought.'

A nominal such as indlu 'house' denotes a set of individual (entities), and in (21), it appears as the argument of the verb 'like', satisfying the selectional restriction (theta-properties) of the verb. The relative clause uSipho á-yíthengí:le in (21) denotes the set of individuals/entities that Sipho bought. Combining indlu and uSipho á-yí-thengí:le yields the right interpretation, with standard set intersection. 
Consider now a case in which the verb in the relative clause requires a locative:

(Ngi-thánd' [DP í:-ndl']) (ú-Síphóá-hlálá kú-yo:na).

I.SM-like 9-house 1-Sipho REL1-live LOC-9.pronoun

'I like the house that Sipho is living in.'

In (22), indlu 'house' denotes a set of entities, just as it did in (21). However, the relative clause ú-Síphó á-hlálá kú-yo:na denotes a set of locations. In other words, what the nominal indlu 'house' denotes and what the relative clause denotes are different sortal types (Rothstein 2009). To account for cases like this, Rothstein (2009) proposes an extra type-shifting mechanism, which can change the denotation of the nominal (from a set of entities to a set of locations) or the denotation of the relative clause (from a set of locations to a set of entities).

In sum, we have seen that locative relatives present problematic issues, including prosodic phrasing (in the case of $\mathrm{Zulu}$ ), mismatches in terms of form, and mismatches in terms of interpretation.

\section{A hybrid analysis}

The formation of relative clauses in the case of Zulu locative relatives has to take care of both the mismatches in form/category, as well as the prosodic properties, i.e., the (locative) head is prosodically phrased separately from the (locative) relative clause.

Various types of mismatch in relative clause formation (e.g., mismatches in Case in Polish (Borsley 1997), and categorial mismatches in English and other languages (van Riemsdijk 2005)) have been noted as problematic for a headraising analysis of relative clauses. Several proposals modifying the head-raising analysis have been put forth in order to solve such mismatches. Below I briefly discuss one recent proposal.

Citko (2001) and Sauerland (2007) independently propose a matching analysis. Though their analyses differ in certain details, we will not distinguish these two proposals here. The matching analysis can be seen as a hybrid analysis: the head noun is base-generated in the matrix, and its corresponding constituent in the relative clause is also generated in the relative clause. Subsequent deletion/ellipsis ensures that the corresponding constituent in the relative clause is not pronounced. This is illustrated in (23):

(23) a. John saw the picture which he likes.

b. John saw [DP the picture [CP [DP which $]_{i}\left[{ }_{T P}\right.$ he likes $\left.\left.\left.t_{i}\right]\right]\right]$ 
The DP the picture in (23) is base-generated external to the relative CP. Within the relative $\mathrm{CP}$, which picture is moved from the object position to the SpecCP in the relative clause. Picture in which picture is subsequently deleted, yielding the sentence in (23a). Note, however, that the relation between the relative CP and the external head is not explicitly discussed in Citko (2001) and Sauerland (2007).

The matching analysis solves the problem of Case mismatches. Since the head of the relative clause is base-generated in the matrix, it will be "assigned" the appropriate Case. On the other hand, in the relative clause, the relative pronoun can also get assigned the Case appropriate to its original position. Note that this analysis not only solves Case mismatches, it also accounts for the lack of condition $\mathrm{C}$ violations in relative clauses. This can be demonstrated with an example like (24) (from Citko 2001), where it is acceptable for the pronoun he to refer to the proper name John, even though it does c-command John in the base position:

a. The picture of $\mathrm{John}_{\mathrm{i}}$ which he $\mathrm{i}_{\mathrm{i}}$ likes is on the front page.

b. [TP [DP the picture of John] [CP [which

The idea is that picture of John in the relative clause is also deletable at LF at the base position, since it is recoverable from the external head. In other words, at LF, there is no offending proper name anymore after the deletion. The matching analysis thus fares better not only in the case of handling mismatches, but also in accounting for the lack of condition $\mathrm{C}$ violations.

\subsection{Proposal}

Sauerland (2007) notes that the matching analysis and the head-raising analysis are two co-existing derivations for relative clauses. The question that arises here is whether a matching analysis can also account for locative relatives in Zulu. Recall that what needs to be accounted for in locative relatives are the mismatches (in form and in interpretation), as well as prosodic phrasing. Consider first the issue of prosodic phrasing. We have seen above that in locative relatives, the head is phrased separately from the rest of the relative clause (regardless of whether it is the matrix that requires a locative, or the relative clause), making locative relatives look like non-restrictive relatives.

Under a matching analysis of locative relatives, since the head is considered to be an external head, the relative clause is no longer a complement of $\mathrm{D}$. (This is in contrast to the Kaynian analysis of non-locative relatives in s shown in the structure below: 
(9), above.) That is, the relative CP is not selected. Thus, given the constraint in (14), we expect the relative CP under a matching analysis to be phrased separately from the head. Note that the lapho...khona clauses which can be used to modify a location are also expected to be phrased separately under (14), since they are adverbial (and therefore unselected) clauses.

The matching analysis, together with the alignment constraint in (14), can thus provide us with the correct prosodic phrasing for locative relatives. We turn now to consider the mismatches in more detail. Let us begin with a simple case of nominal relatives, where both the matrix and the relative clause require only a nominal element:

$$
\begin{aligned}
& \text { (Ngi-thánd' i-ndl' [ u-Síph' á-yí-thengí:le ]). } \\
& \text { I.SM-like 9-house 1-Sipho REL1-9OM-bought } \\
& \text { 'I like the house that Sipho bought.' }
\end{aligned}
$$

As we have noted above, in an object relative like (25), the object is "resumed" by an agreeing object marker. (In (25), it is yi.) Under a head-raising analysis, the object marker can be considered to be either an agreement marker or an object clitic. ${ }^{8}$ In a locative relative, when the relative clause requires a locative, we do not have an object marker of the type we see in (25), but rather a strong pronoun, as shown in (26):

$$
\begin{aligned}
& \text { (Ngi-thánd' [Dp í:-ndl']) (ú-Síphóá-hlálá kú-yo:na). } \\
& \text { I.SM-like 9-house 1-Sipho REL1-live LOC-9.pronoun } \\
& \text { 'I like the house that Sipho is living in.' }
\end{aligned}
$$

The presence of the strong pronoun in these cases may be due to the fact that there is no locative equivalent to the object marker in Zulu. Instead, what we see in (26) is a strong pronoun with locative marking (i.e., $k u$ ). Consider now how a matching analysis would handle such cases. One of the important mechanisms needed in the matching analysis is the ellipsis of the internal head. The example in (27) shows that the verb -hlala 'live' requires a locative of the form e-N-ini:

$$
\begin{aligned}
& \text { (Ú-hlálá é-dolóbh-e:ni). } \\
& \text { 1SM-lives LOC-5.city-LOC } \\
& \text { 'She lives in town.' }
\end{aligned}
$$

8 See Buell, Cheng and Schadeberg (in prep.) for a discussion on the nature of object markers in Zulu. 
Under a matching analysis, with head-raising in the relative clause, we have the structure in (28) for the sentence in (26):

Ngi-thánd' í:-ndl’ [ср e-ndl-ini [IP ú-Síphó á-hlálá kú-yo:na]].

Leaving aside the issue of the strong pronoun (and the form ku-yona in particular), the structure in (28) highlights the issue of identity under the deletion/ellipsis mechanism which is needed for the matching analysis. If phonological identity is required, ellipsis/deletion would not apply in (28). An alternative to a matching analysis, but maintaining the external head, is in fact the old style relative clause analysis (Chomsky 1977) an adjunction analysis with an empty operator, as in (29):

Ngi-thánd' [DP [NP [NP í:-ndl’] [CP OP ú-Síphó á-hlálá kú-yo:na]]].

With an empty operator, not only is the identity for ellipsis not an issue, the issue of mismatches also does not arise. Furthermore, the prosodic properties of the locative relatives can be easily captured since the relative $\mathrm{CP}$ is not a selected CP, and thus is subject to the prosodic Alignment constraint in (14).

\subsection{Predictions and further issues}

Similar to Sauerland (2007), we consider the empty operator analysis to be another relative formation strategy, co-existing with the head-raising analysis and the matching analysis. Nonetheless, an empty operator analysis differs fundamentally from a head-raising (e.g., Kaynian) or a matching analysis. In particular, while a head-raising or a matching analysis predicts reconstruction effects (that is, the head can be interpreted in the relative clause), an old style empty operator analysis does not.

Following Bhatt (2002), we tested for reconstruction effects through high versus low readings with adjectival modifiers in Zulu. Preliminary results are compatible with our proposal, namely, that nominal relatives are formed using a head-raising analysis while locative relatives are formed with an empty operator. This is illustrated in the sentences in (30):
a. (Í-ncwadi énde kuna-zo zó:-nke) (ú-Sípho â:-th' 9-book long than-9 9.every 1-Sipho REL1-say ú-Síbúsísó Nyémbezi w-á-yi-bhá:la) (yí-le:na.) 1-Sibusiso Nyembezi 1SM-TAM-9OM-write 9-DEM 'The longest book that Sipho says that uSibusiso Nyembezi has written was this one.' 
b. (Ú-Sí:pho ú-thí í-ndl' éndala kúna-zo zó:nk') 1-Sipho 1SM-said 9-house 9.old than-9 9.every (ú-Thémb' á:-ngena kú-zo:na) (yí-le:na.)

1-Themba REL1-enter LOC-10.pronoun 9-DEM

'Sipho said that the oldest house that Themba has gone into is this one.'

c. \#índl' éndala kúnazo zó:nk' ú-Síph' á-th' ú-Thémba w-â:-nge:ná kúyo:na yíle:na.

The contrast between (30a) and (30b) shows that in the case of locative relatives, the low reading requires the locative to be lower in the embedding, not in the matrix clause. This implies that the nominal relative and the locative relative have different reconstruction possibilities.

\subsubsection{Remaining puzzles}

There are some cases of locative relatives where the locative head does not have to be phrased separately from the relative clause.
a. (Índaw' ú-Síph’ â:-khandelá kú-yón’ í-mo:t') (í-shí:le.)
9.place 1-Sipho REL1-fix LOC-9.pronoun 9-car 9SM-burn.TAM
'The place where Sipho fixed the car burned down.'
b. In answering the question: which house do you like?
(Ngi-thánda í-ndl' u-Thémb' a-hlálá kú-yo:na)
I.SM-like 9-house 1-Themba REL1-live LOC-9.pronoun
'I like the house that Themba lives in.'

These sentences on the surface seem to be entirely contradictory to the data that we have discussed above. Recall that in English, locative relatives do not allow complementizer or relative pronoun deletion. Compare the examples in (32) and (33):

(32) a. The book which/that/ø Mary read is out of print.

b. The shop where/in which $/ *^{*}$ that $/ *^{*} \varnothing$ Mary bought the book is on the corner of the street.

(33) a. The place which/that/ø I painted [DP $t]$ is on the corner of the street.

b. The place where/in which/ø I painted (the picture) $[\mathrm{pP} t]$ is on the corner of the street.

When the head of the locative relative is shop, as in (32), either a relative pronoun or a complementizer must be used. In contrast, if the head is place, the complementizer or the relative pronoun can be deleted. Rothstein (2009) argues that place in English is ambiguous in its denotation - both individuals and 
locations are possible. Under Rothstein's (2009) analysis, place, due to its ambiguous denotation, does not require the relative clause to type-shift, which is apparently the reason why an overt relative pronoun or a complementizer must be present. In English, not all nouns can denote locations: place can, but shop cannot. Following Rothstein, we suggest that in Zulu, both indawo 'place' and indlu 'house' can denote locations.

Rothstein (2009) suggests that the ambiguity between an entity and nonentity domain can be extended potentially to other domains, such as manner, reason and temporal domains. The examples in (34) show that way, reason, as well as day/hour/moment can denote in another domain than individuals/entities:

(34) a. The way /*manner in which/ø he painted the house [PP t] surprised me.

b. The reason why/ø he did it... (cf. *explanation)

c. The day/hour/moment/*meeting at which/when/ø he made the announcement upset me.

The sentences in (35) suggest that in Zulu, usuku 'day' and indlela 'way' can also denote within the temporal domain and the manner domain respectively:
a. (Ngi-thánd' ín-dlel'á-cúla nga:-yo).
I.SM-like 9-way REL1-sing PREP-9
'I like the way he sings.'
b. (Ú-súk' ú-Síph' á-phekelé nga-l' é-mz-ini wá:kho)
11-day 1-Sipho REL1-cook PREP-11 LOC-3.home-LOC 3.your (lú-qalé ka:mbi).
11 sM-begin badly
'The day when Sipho cooked at your house began badly.'

In the sentences in (35), the head nouns usuku 'day' and indlela 'way' do not phrase separately from the rest of the relative clause, suggesting that these elements can denote both individuals and within other domains.

Before closing this section, we would like to briefly compare English and Zulu. In English, according to Rothstein, type-shifting is needed to reconcile the mismatch in interpretation. Since such locative relatives do not allow deletion of the relative pronoun or the complementizer, one may conclude that typeshifting needs to be overtly marked. The question then arises in the case of Zulu as to how type-shifting is marked. Under the analysis proposed here, Zulu locative relatives employ the empty operator strategy. Similar to other relatives in Zulu, there is no overt marking. However, in the cases of unambiguous locative elements in Zulu, type-shifting should still be needed to provide the 
correct interpretation. But there does not seem to be any requirement for overtly marking such a type-shifting mechanism.

\section{Conclusion}

We have shown that locative relatives in Zulu have a different prosodic phrasing than nominal relatives, in that the head of a locative relative is phrased separately from the rest of the relative clause. We propose that the best way to account for locative relatives in Zulu is to resort to the old style adjunction analysis of relative clauses, involving an empty operator.

Turning back to the question concerning the categorical status of locative expressions in Zulu, we have seen that locative relatives differ from nominal relatives, suggesting that we are not dealing with a nominal category. However, the differences we have seen in Zulu can be due to something other than categorical mismatches (for instance, mismatches in interpretation). Further, Zulu has a very impoverished locative system. To get to understand further what drives the differences we have seen above, it is thus essential that we investigate other Bantu languages with a fuller locative system (i.e., with several locative noun classes), and examine the behaviors of locative relatives in contrast with nominal relatives.

\section{References}

Bianchi, V. (2000). The raising analysis of relative clauses: a reply to Borsley. Linguistic Inquiry 31, 123-140.

Bresnan, Joan W. \& Jonni Kanerva. (1989). Locative inversion in Chichewa. Linguistic Inquiry 20, 1-50.

Bresnan, Joan W. (1994). Locative inversion and the architecture of Universal Grammar. Language 70, 72-131.

Borsley, Robert. (1997). Relative clauses and the theory of phrase structure. Linguistic Inquiry 28, 629-647.

Buell, Leston. (2007). Semantic and formal locatives: implications for the Bantu locative inversion typology. SOAS Working Papers in Linguistics 15, 105-120.

Buell, Leston, Lisa L.-S. Cheng \& Thilo Schadeberg. in prep. Word order and morphological marking in Bantu languages. Ms., Leiden University.

Cheng, Lisa L.-S. \& Laura J. Downing. (2007). The prosody and syntax of Zulu relative clauses. SOAS Working papers in Linguistics 15, 51-63.

Cheng, Lisa L.-S. \& Laura J. Downing. (2009). Where's the topic in Zulu? In Helen de Hoop \& Geertje van Bergen (eds.), Special issue on Topics Cross-linguistically, The Linguistic Review 26, 207-238. 
Cheng, Lisa L.-S. \& Laura J. Downing. to appear, a. Clefts in Durban Zulu. In Andreas Haida, Katherina Hartmann \& Tonjes Veenstra (eds.), The Structure of Clefts. Amsterdam: John Benjamins.

Cheng, Lisa L.-S. \& Laura J. Downing. to appear, b. Against FocusP: arguments from Zulu. In Ivona Kucerova and Ad Neeleman (eds.), Information Structure: Contrasts and Positions. Cambridge: Cambridge University Press.

Chomsky, Noam. (1977). On wh-movement. In P. Culicover, T. Wasow, and A. Akmajian,eds., Formal syntax. New York: Academic Press, 71-132.

Citko, Barbara. (2001). Deletion under identity in relative clauses. In M. Kim and U. Straus (eds.) NELS 31.

Clech-Darbon, Anne, Georges Rebuschi \& Annie Rialland. (1999). Are there cleft sentences in French? In G. Rebuschi \& L. Tuller (eds.), The Grammar of Focus. Amsterdam: Benjamins, 83-118.

Demirdache, Hamida. (1991). Resumptive Chains in Restrictive Relatives, Appositives and Dislocation Structures. PhD dissertation, MIT.

Demuth, Katherine. (1990). Locatives, impersonals and expletives in Sesotho. The Linguistic Review 7, 233-249.

Doke, Clement M. (1961). Textbook of Zulu Grammar. 6th edition. London: Longmans.

Kayne, Richard. (1994). The Antisymmetry of Syntax. Cambridge, Mass: MIT Press.

Khumalo, James S. M. (1987). An Autosegmental Account of Zulu Phonology. PhD dissertation, University of the Witwatersrand.

Koch, Karsten. (2008). Intonation and focus in Nlekepmxcin (Thompson River Salish). PhD dissertation, University of British Columbia.

Larson, Richard. (1985). Bare NP Adverbs. Linguistic Inquiry 16, 595-621.

Pesetsky, David \& Esther Torrego. (2006). Probes, goals and syntactic categories. Proceedings of the $7^{\text {th }}$ annual Tokyo Conference on Psycholinguistics.

Rebuschi, Georges. (2005). Generalizing the antisymmetric analysis of coordination to nominal modification. Lingua 115, 445-459.

van Riemsdijk, Henk. (2005). Free relatives. In M. Everaert, H. van Riemsdijk, R. Goedemans \& B. Hollebranse (eds.), The Blackwell Companion to Syntax, vol. 2. Oxford: Blackwell, 338-382.

Rothstein, Susan. (2006). Locatives, locations and other entities. Paper presented at the Semantics Circle Meeting, Tel Aviv.

Rothstein, Susan. (2009). Domain selection and complementiser deletion. Paper presented at the Non-Canonical Predication Workshop, the University of Western Ontario.

Sauerland, Uli. (2007). Unpronounced heads in relative clauses. In Kerstin Schwabe \& Susanne Winkler (eds.), The Interfaces: Deriving and Interpreting Omitted Structures. Amsterdam: John Benjamins, 205-226. 


\section{Locatives in Durban Zulu}

Zeller, Jochen. (2004). Relative clause formation in the Bantu languages of South Africa. Southern African Linguistics and Applied Language Studies 22 (1\&2), 75-93. 